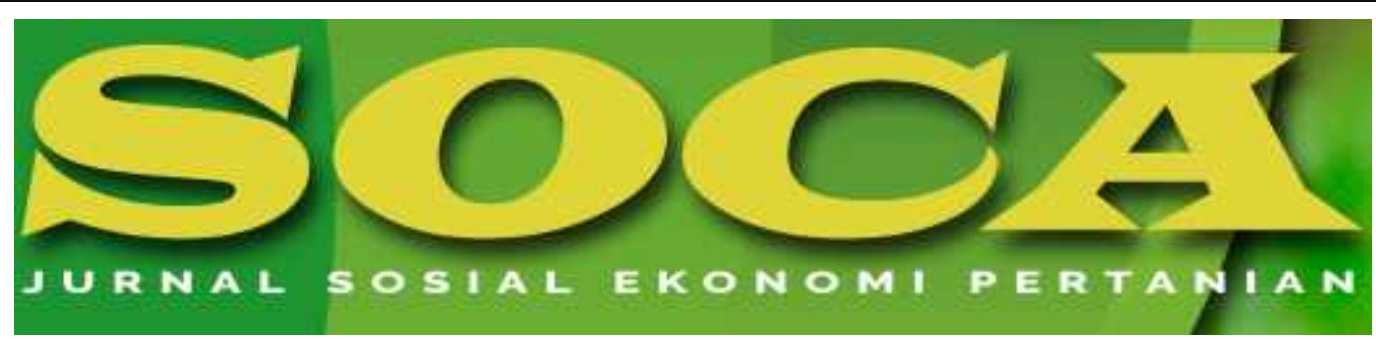

https://ojs.unud.ac.id/index.php/soca

\title{
ANALISA KEUNTUNGAN USAHA PETERNAKAN AYAM BROILER POLA MANDIRI DI KABUPATEN MALANG (Studi Kasus Di Kecamatan Karangploso Kabupaten Malang)
}

\author{
Ariani Trisna Murti ${ }^{1}$, Karunia Setyowati Suroto ${ }^{1}$, dan Hidayati Karamina ${ }^{2}$ \\ 1. Program Studi Peternakan, Fakultas Pertanian Universitas Tribhuwana Tunggadewi \\ 2. Program Studi Agroteknologi, Fakultas Pertanian Universitas Tribhuwana Tunggadewi \\ Email kores[pondensi: artrimur@gmail.com,niekarunia@gmail.com, \\ hidayatikaramina@yahoo.com \\ Telepon/HP: 082143162595, 081334569452, 082245457666
}

Kata Kunci:
Keuntungan,
Broiler, dan
Usaha Pola
Mandiri

\begin{abstract}
Abstrak
Penelitian dilaksanakan pada beberapa peternak ayam broiler pola mandiri di Kecamatan Karangploso Kabupaten Malang Provinsi Jawa Timur. Jenis penelitian yang dilakukan adalah penelitian kuantitatif. Pemilihan lokasi dilakukan atas pertimbangan bahwa berdasarkan data sekunder yang diperoleh dari Dinas Peternakan dan Kesehatan Hewan Provinsi Jawa Timur menyatakan bahwa Kecamatan Karangploso merupakan salah satu kawasan yang memiliki populasi ayam pedaging terbesar di Kabupaten Malang sejumlah 1.044.402 pada tahun 2018 (Dinas Peternakan Kabupaten Malang, 2018). Tujuan dari penelitian yaitu untuk menganalisis rataan jumlah pendapatan dan besaran keuntungan yang dihasilkan dari usaha peternakan ayam broiler pola mandiri di Kecamatan Karangploso Kabupaten Malang. Pengumpulan data dilaksanakan pada bulan Januari 2019 - Februari 2019 dengan metode purposive sampling dengan kriteria. Sampel yang digunakan yaitu seluruh peternak ayam broiler pola mandiri sejumlah 13 responden. Analisa kuantitatif dihitung dari total penerimaan, pendapatan, rasio $\mathrm{R} / \mathrm{C}$, BEP, ROI, dan Payback Period (PBP). Hasil penelitian dapat ditarik kesimpulan yaitu usaha ternak ayam pedaging pola mandiri di Kecamatan Karangploso layak untuk dikembangkan. Nilai besaran perhitungan dari R/C rasio, BEP, dan ROI yang meningkat dari tahun ke tahun. Nilai rataan $\mathrm{R} / \mathrm{C}$ ratio $>1$, yaitu sebesar $1,07 \%$. Rataan nilai BEP, ROI, dan PBP meningkat dari tahun 2016 sampai dengan 2018, sehingga usaha ternak ayam broiler pola
\end{abstract}


mandiri dapat dinyatakan menguntungkan dan layak

untuk dikembangkan.

\section{ANALYSIS OF PROFIT ANALYSIS OF MANDIRI PATTERN BROILER LIVESTOCK ANIMAL HUSBANDRY IN MALANG DISTRICT (Case Study in Karangploso District, Malang Regency)}

\section{Keywords: \\ Profitability, \\ Broiler, Independent Bussiness}

\begin{abstract}
Abstrak
The study was conducted on several independent pattern broiler breeders in Karangploso District, Malang Regency, East Java Province. This type of research is quantitative research. The choice of location is based on the consideration that based on secondary data obtained from the Animal Husbandry and Animal Health Office of East Java Province, it is stated that Karangploso Subdistrict is one of the regions with the largest broiler population in Malang, amounting to 1,044,402 in 2018 (Malang Animal Husbandry, 2018). This aim of this research is to analyze the average amount of income and the amount of profit generated from independent pattern broiler chicken farming in Karangploso District, Malang Regency. Data collection was carried out in January 2019 - February 2019 with a purposive sampling method with criteria. The sample used is all independent breeders of broiler chicken with a total of 13 respondents. Quantitative analysis is calculated from total revenue, revenue, $R$ / $C$ ratio, BEP, ROI, and Payback Period (PBP). The results can be concluded that the independent pattern of broiler business in Karangploso District is feasible to be developed. The calculated value of the $R / C$ ratio, BEP, and $R O I$ is increasing from year to year. The average $R / C$ ratio $>1$, which is $1.07 \%$. The average value of BEP, ROI, and PBP increased from 2016 to 2018, so that the independent broiler chicken breeding business can be declared profitable and feasible to be developed.
\end{abstract}

How to Cite (APA 6th Style):

Murti, A. T., Suroto, K. S., \& Karamina, H. (2020). Analisa Keuntungan Usaha Peternakan Ayam Broiler Pola Mandiri Di Kabupaten Malang (Studi Kasus Di Kecamatan Karangploso Kabupaten Malang). SOCA: Jurnal Sosial Ekonomi Pertanian, 14(1), 40-54.

https://doi.org/https://doi.org/10.24843/SOCA.2020.v14.i01.p04

\section{PENDAHULUAN}

Meningkatnya pertumbuhan jumlah masyarakat Indonesia dari tahun ke tahun secara otomatis berdampak pada tingginya kesadaran masyarakat akan gizi. Dampak yang ditimbulkan adalah meningkatnya permintaan akan kebutuhan protein, baik protein hewani maupun nabati. Peternakan merupakan subsektor penting sebagai penyedia kebutuhan protein hewani. Salah satu produk peternakan penyumbang terbesar untuk memenuhi kebutuhan adalah daging ayam negeri, atau 
biasa disebut dengan daging ayam potong. Peternakan ayam pedaging baik dalam skala kecil, menengah, dan juga besar mempunyai peluang dan prospek usaha yang sangat baik untuk dijalankan. Ayam pedaging merupakan salah satu komoditi ternak unggulan, hal ini terutama disebabkan ayam broiler mempunyai masa panen yang relative singkat yaitu 30-40 hari. Pertumbuhan bobot badan ayam broiler relatif cepat yaitu pada umur lima atau enam minggu dengan rata - rata bobot badan mencapai 1,4 kg - 1,6 kg (Yemima, 2014). Produksi daging ayam ras pedaging masih mengalami angka fluktuatif secara nasional. Produksi ayam pedaging secara berurutan pada tahun 2015 sebesar 1.628 .310 ton, tahun 2016 sebesar 1.905 .500 ton, pada tahun 2017 sebesar 1.848.060 ton (Badan Pusat Statistik, 2017).

Rana et al., (2012) menyatakan bahwa keuntungan merupakan tujuan terbesar untuk setiap usaha peternakan yang dijalankan bersamaan dengan adanya berbagai tantangan sesuai dengan skala usaha yang dijalankan. Tantangan yang harus dihadapi dalam usaha budidaya ayam broiler diantaranya adalah lemahnya manajemen pemeliharaan. Lemahnya manajemen pemeliharaan disebabkan karena broiler merupakan jenis ternak unggas hasil dari persilangan dan seleksi yang rumit sehingga membutuhkan pemeliharaan yang intensif. Fluktuasi atau perubahan harga kebutuhan pakan, Day Old Chicken (DOC), dan obat - obatan yang tidak menentu secara otomatis mempengaruhi keseimbangan harga antara permintaan dan penawaran akan daging broiler. Perbedaan kondisi dimana permintaan lebih rendah daripada penawaran, hal tersebut yang mengakibatkan adanya ketidakpastian peternak untuk menjual daging broiler siap potongnya. Peternak akan menjual hasil produksinya disaat harga dapat meningkat lebih baik daripada mereka menjual murah hasil ternaknya. Keadaan demikian membuat peternak terpaksa harus mengeluarkan biaya tambahan untuk biaya pakan dan budidaya yang memakan waktu lebih lama. Besaran margin keuntungan di setiap siklus produksi usaha budidaya sangat tipis yaitu sebesar 5\% sampai dengan angka 10\%. Harga kebutuhan untuk budidaya merupakan faktor penghambat yang besar dan berpengaruh terhadap banyaknya total biaya yang harus dikeluarkan oleh peternak. Beberapa contoh kebutuhan adalah produk impor bahan baku pembuatan ransum, feed supplement, vaksin, dan obat-obatan. Produksi ayam broiler penting bagi perekonomian selain untuk memenuhi kebutuhan gizi masyarakat dan menambah penghasilan, juga bermanfaat untuk meningkatkan lapangan pekerjaan.

Usaha peternakan dapat dikembangkan dengan berbagai pola, yaitu pola mandiri dan pola kemitraan. Kegiatan pemasokan sarana produksi hingga proses kegiatan pemasaran hasil produksi usaha dilakukan sendiri oleh peternak ayam broiler yang berpola mandiri. Peternak sebagai penanggung semua modal yang diperlukan seperti Day Old Chicken (DOC), kandang, peralatan tenaga kerja, obat obatan, tenaga kerja, sapronak, sampai dengan sistem pemasaran. Peternak mempunyai kewajiban untuk memasarkan sendiri produksi usahanya. Prinsip dari usaha peternakan adalah menyediakan seluruh input sampai dengan output produksinya, sehingga resiko dan keuntungan sepenuhnya ditanggung oleh peternak (Supriyatna dkk, 2009).

Kabupaten Malang merupakan daerah penghasil daging ayam potong dikarenakan terdapat beberapa daerah penghasil populasi ayam broiler. Berdasarkan Data Dinas Peternakan dan Kesehatan Hewan Kabupaten Malang terdapat tiga daerah dengan populasi ayam broiler, salah satunya adalah Kecamatan 
Karangploso. Kecamatan Karangploso menduduki peringkat ketiga terbesar setelah Kecamatan Dampit dan Kecamatan Bululawang. Kecamatan Karanploso mencatat pada triwulan II tahun 2018 menjadi daerah penyuplai populasi ayam broiler sebanyak 1.044.402 di Kabupaten Malang. Berdasarkan data tersebut dapat disimpulkan bahwa Kecamatan Karangploso mempunyai potensi sebagai salah satu daerah penghasil daging ayam broiler di wilayah Kabupaten Malang. Berdasarkan jenis usaha peternakan yang terdapat di Kecamatan Karangploso yaitu pola mandiri, menyebabkan adanya implikasi terhadap perhitungan total biaya produksi yang dikeluarkan, pendapatan dan keuntungan usaha peternakan ayam broiler yang dijalankan dan dihasilkan. Perlu adanya suatu kajian dan analisa untik mengetahui tingkat keuntungan yang dapat dicapai oleh peternak, dengan demikian penting adanya penelitian ini dilakukan. Penelitian bertujuan untuk mengetahui dan menganalisis rataan pendapatan dan keuntungan usaha peternakan broiler pola mandiri ditinjau dari tingkat efisiensi produksi. Hasil dari penelitian dapat menjadi bahan rujukan bagi peternak untuk mengevaluasi usaha peternakan yang telah dijalankan.

\section{METODOLOGI PENELITIAN}

\section{Kerangka Teoritis}

Total biaya produksi yang dikeluarkan dan penerimaan yang diperoleh dari hasil produksi usaha merupakan sebuah tolok ukur penting dari keberhasilan suatu usaha. Margin antara total biaya produksi dan penerimaan suatu usaha merupakan hal penting yang harus diketahui dan dianalisa oleh pemilik usaha agar kegiatan produksi usaha dapat dijalankan secara efisien. Nilai efisiensi usaha dapat dilihat dari selisih adan perbandingan nilai output terhadap input, namun pendapatan yang dinilai besar tidak selalu dapat menggambarkan keuntungan yang juga besar. Penggunaan input tetap lebih dapat dioptimalkan pada produksi usaha skala yang besar daripada usaha skala kecil.

Metode analisa yang digunakan antara lain: 1) Titik Impas (Break Even Point) yaitu analisis yang digunakan untuk mengetahui pada skala dan nilai penjualan berapa perusahaan tidak memperoleh laba juga tidak menderita kerugian. Analisis titik impas ini akan memudahkan peternak untuk mengetahui pada tingkat penjualan, tingkat skala pemeliharaan, tingkat perolehan laba dalam usaha yang dijalankan ; 2) Return on investment merupakan analisa yang digunakan untuk mengukur kemampuan perusahaan dengan dana keseluruhan yang ditanamkan dalam modal yang digunakan untuk operasi perusahaan dalam mendapatkan keuntungan, 3). Payback period (PP) merupakan analisa perhitungan periode jangka waktu untuk dapat mengembalikan biaya investasi suatu usaha ; 4) Rasio R/C (Revenue Cost Ratio) merupakan perhitungan dan perbandingan antara total penerimaan dan total biaya produksi, selain itu untuk mengukur seberapa efisien input yang digunakan.

\section{Waktu dan Tempat Penelitian}

Penelitian dilaksanakan pada tanggal 5 Januari 2019 sampai dengan 6 Februari 2019 di tempat penelitian yaitu Kecamatan Karangploso Kabupaten Malang Provinsi Jawa Timur. Lokasi penelitian dipilih secara sengaja (purposive). Lokasi 
penelitian dipilih atas dasar pertimbangan yang dirujuk dari data Dinas Peternakan dan Kesehatan Hewan Kabupaten Malang. Data dari Dinas Peternakan dan Kesehatan Hewan Kabupaten Malang mencatat bahwa Kecamatan Karangploso Kabupaten Malang merupakan salah satu wilayah penghasil daging broiler terbesar ketiga dengan kepemilikan populasi sebesar 1.044.402 di Tahun 2018.

Jenis penelitian yang digunakan dalam penelitian ini adalah penelitiian kuantitatif. Menurut Sugiono (2013), metode penelitian yang berlandaskan filsafat positivisme dapat disebut dengan metode penelitian kuantitatif. Metode penelitian tersebut digunakan untuk meneliti pada populasi atau sampel tertentu, teknik pengambilan sampel pada umumnya dilakukan secara random, pengumpulan data menggunakan instrumen penelitian, analisis data bersifat kuantitatif/statistik. Tujuan dari metode penelitian kuantitatif adalah untuk menguji kebenaran akan hipotesis yang sebelumnya telah ditentukan dan ditetapkan.

\section{Pengumpulan Sampel Data}

Metode pengambilan data dari sampel dilakukan secara sengaja atau biasa disebut purposive sampling. Populasi dalam penelitian ini merupakan peternak broiler yang menjalankan usaha secara mandiri di Kabupaten Malang. Sugiyono (2016:85) berpendapat bahwa: "Purposive Sampling adalah teknik pengambilan sampel sumber data dengan pertimbangan tertentu." Alasan menggunakan teknik Purposive Sampling adalah karena tidak semua sampel memiliki kriteria yang sesuai dengan fenomena yang diteliti. Oleh karena itu, peneliti memilih teknik Purposive Sampling yang menetapkan berbagai pertimbangan. Beberapa sampel yang digunakan dalam penelitian harus memenuhi syarat atau kriteria-kriteria tertentu yang telah ditetapkan dalam penelitian. Kriteria pengambilan sampel pada penelitian adalah yang pertama sampel penelitian merupakan peternak usaha ayam broiler pola mandiri yang ada di Kecamatan Karangploso Kabupaten Malang yang mempunyai kepemilikan populasi 8000 - 13000 ekor ayam broiler, usaha sudah dijalankan lebih dari 1 tahun, dan analisa usahanya dihitung selama 3 periode. Sampel penelitian diambil di sejumlah 5 Desa di Kecamatan Karangploso, yakni Desa Bocek, Desa Tawangagro, Desa Ngenap, Desa Ngijo, dan Desa Donowarih. Alasan penentuan sampel pada 5 desa karena kelima desa tersebut merupakan jumlah populasi terbesar yaitu 318.500 ekor ayam pedaging, dengan jumlah peternak 30 peternak ayam pedaging. Jumlah sampel peternak broiler pola mandiri sebanyak 13 orang, dari 13 orang tersebut dapat diambil sampel sebanyak 5 peternak.

\section{Analisa Data}

Perhitungan analisa profitabilitas usaha peternakan dapat diketahui dengan menggunakan cara perhitungan biaya dan pendapatan. Tahapan yang dilakukan yaitu yang pertama dengan cara : 1) biaya - biaya produksi dikelompokkan menurut jenisnya, yaitu pengelompokkan biaya tetap dan biaya tidak tetap (variable), 2) melakukan analisa perhitungan pada masing-masing tahapan, 3) menghitung dan menganalisis hasil perhitungan pada beberapa tahapan dan dibandingkan dengan pustaka mengenai syarat dan ketentuan mengenai parameter keberhasilan suatu usaha. 


\section{Variabel Penelitian}

Pendapatan merupakan variable yang digunakan didalam penelitian ini. Total penerimaan dan total biaya merupakan unsur yang menjadi sub variable. Berikut merupakan dasaran indikator pengukuran:

\begin{tabular}{|c|c|c|}
\hline Tidak tetap (variabel) & $\begin{array}{l}\text { Sub tidak tetap } \\
\text { (variabel) }\end{array}$ & Indikator pengukuran \\
\hline 1) R/C RATIO & Total biaya (TC) & Biaya tetap: \\
\hline 2) $\mathrm{BEP}$ & & a) Penyusutan Kandang \\
\hline 3) $\mathrm{ROI}$ & & b) Penyusutan peralatan \\
\hline 4) PAYBACK & & Biaya tidak tetap (variabel): \\
\hline PERIOD & & a) Biaya bibit \\
\hline & & b) Pakan \\
\hline & & c) Tenaga kerja \\
\hline & & d) Biaya obat dan vaksin \\
\hline & & e) Biaya listrik \\
\hline & $\begin{array}{l}\text { Total } \\
\text { penerimaan (TR) }\end{array}$ & Penjualan ayam pedaging \\
\hline
\end{tabular}

\section{HASIL DAN PEMBAHASAN}

\section{Biaya Produksi}

Biaya yang dikeluarkan untuk semua proses produksi terdiri dari biaya tetap dan biaya variabel. Biaya tetap dan biaya variabel adalah keseluruhan besaran biaya yang wajib dikeluarkan secara terus menerus dan bersifat fluktuatif untuk menunjang segala kegiatan selama proses produksi berjalan. Tujuan dari usaha dan proses produksi itu sendiri adalah untuk dapat mencapai keuntungan semaksimal mungkin dengan modal dan biaya produksi seminimal mungkin. Taufik, dkk (2013) menjelaskan bahwa biaya produksi merupakan segala pengeluaran yang dibutuhkan dan harus dikeluarkan oleh produsen untuk memperoleh faktor faktor produksi dan bahan penunjang lainnya yang dapat digunakan agar produk tertentu yang telah direncanakan dapat terwujud dengan baik. Biaya produksi digolongkan menjadi biaya tetap dan biaya tidak tetap.

Biaya yang harus dikeluarkan oleh usaha peternakan ayam broiler di Kecamatan Karangploso yaitu terdiri dari biaya tetap (fixed cost) dan biaya variabel (variable cost). Biaya tetap yang harus dikeluarkan peternak ayam broiler pola mandiri di Kecamatan Karangploso terdiri dari penyusutan kandang, peralatan, (PBB) pajak bumi dan bangunan, sedangkan biaya yang dikeluarkan untuk sarana produksi ternak seperti bibit day old chicken (DOC), biaya pakan, vaksin, obatobatan, LPG, listrik dan juga listrik dan sekam tergolong biaya variabel. Besarnya biaya produksi usaha peternakan broiler di Kabupaten Malang dijelaskan pada tabel 1 di bawah ini: 
Tabel 1. Rataan Biaya Produksi Usaha Peternakan Broiler Pola Mandiri Kabupaten Karangploso

\begin{tabular}{cccccccc}
\hline \multirow{2}{*}{ Peternak } & Populasi & \multicolumn{9}{c}{2016} & & \multicolumn{2}{c}{2017} \\
\cline { 3 - 8 } & & Biaya Tetap & $\begin{array}{c}\text { Biaya tidak } \\
\text { tetap (variabel) }\end{array}$ & Biaya Total & Biaya Tetap & $\begin{array}{c}\text { Biaya tidak } \\
\text { tetap (variabel) }\end{array}$ & Biaya total \\
\hline Pak Suyetno & 8.000 & 7.939 .999 & 235.933 .000 & 243.872 .999 & 7.989 .999 & 245.096 .000 & 253.085 .999 \\
Pak Supriadi & 9.000 & 9.233 .333 & 284.800 .000 & 294.033 .333 & 9.233 .333 & 291.060 .000 & 300.293 .333 \\
Pak Suyono & 10.000 & 9.782 .500 & 280.743 .000 & 290.525 .500 & 9.812 .500 & 309.172 .500 & 318.985 .000 \\
Ibu Ani & 12.000 & 17.003 .332 & 334.507 .000 & 351.510 .332 & 17.033 .332 & 367.145 .000 & 384.178 .332 \\
Pak Adi & 13.000 & 11.824 .000 & 378.725 .500 & 390.549 .500 & 11.874 .000 & 390.141 .000 & 402.015 .000 \\
\hline Total & & 55.783 .164 & 1.514 .714 .500 & 1.570 .761 .664 & 55.943 .164 & 1.602 .614 .500 & 1.658 .557 .664 \\
\hline
\end{tabular}

Tabel 1 Lanjutan. Rataan Biaya Produksi Usaha Peternakan Broiler Pola Mandiri Kabupaten Karangploso

\begin{tabular}{ccccc}
\hline \multirow{2}{*}{ Peternak } & Populasi & \multicolumn{3}{c}{2018} \\
\cline { 3 - 5 } & & Biaya Tetap & $\begin{array}{c}\text { Biaya tidak } \\
\text { tetap (variabel) }\end{array}$ & Biaya Total \\
\hline Pak Suyetno & 8.000 & 8.096 .666 & 259.270 .000 & 267.366 .666 \\
Pak Supriadi & 9.000 & 9.293 .333 & 310.235 .000 & 319.528 .333 \\
Pak Suyono & 10.000 & 9.825 .500 & 321.150 .000 & 330.975 .500 \\
Ibu Ani & 12.000 & 17.053 .332 & 381.770 .000 & 398.823 .332 \\
Pak Adi & 13.000 & 11.924 .000 & 412.230 .000 & 424.154 .000 \\
\hline Total & & 56.192 .831 & 1.684 .655 .000 & 1.740 .847 .831
\end{tabular}

Sumber: Data Primer Diolah (2019)

Pengolahan data pada Tabel 1 menggambarkan bahwa total biaya produksi yang dikeluarkan peternak broiler pola mandiri di Kecamatan Karangploso secara berurutan pada tahun 2016 adalah sebesar Rp.1.570.761.664, pada tahun 2017 sebesar Rp.1.658.557.664, dan pada tahun 2018 sebesar Rp.1.740.847.831. Biaya produksi dalam kurun waktu 3 tahun yaitu 2016, 2017, dan 2018 mengalami peningkatan secara terus menerus. Peningkatan biaya produksi setiap tahunnya dapat dilihat dari biaya pembelian DOC, dan pakan. Keduanya mempunyai peningkatan secara signifikan dibandingkan dengan biaya variabel lain. Mufid dan Wawan (2016) menjelaskan bahwa setiap periode masa panen biaya yang dikeluarkan bersifat fluktuatif atau naik turun. Besaran biaya yang paling banyak dikeluarkan adalah pada biaya pakan. Biaya pakan tidak dapat bernilai konstan pada satu harga dan satu jenis pakan disetiap periode produksinya. Beberapa faktor yang menyebabkan peternak memiliki biaya pakan yang lebih besar, di karenakan keseluruhan pakan yang diberikan pada ternak merupakan pakan jadi atau komplit baik untuk fase starter maupun finisher sehingga dalam pemeliharaan ayam pedaging tidak terjadi kekurangan pakan. Harga pakan dihadapkan pada keadaan dimana besaran tingkat harga bahan baku untuk pembuatan pakan, hal tersebut 
yang menyebabkan harga pakan itu sendiri cenderung fluktuatif, kapan saja bias naik dan turun (Solihin, 2009).

\section{Penerimaan}

Jumlah barang dan jasa yang mampu dibeli oleh konsumen selama jangka waktu tertentu berdasarkan selera dan pendapatan masyarakat dapat disebut dengan penerimaan. Jangka dan kurun waktu tersebut dapat satu jam, satu hari, satu tahun atau periode lainya. Selera, harga suatu barang, besaran pendapatan konsumen, keyakinan konsumen akan barang tertentu, periklanan, dan sebagainya merupakan keadaan - keadaan yang harus dipertimbangkan (Pappas, 1995). Berikut ini merupakan hasil perhitungan penerimaan usaha peternakan broiler pola mandiri dapat digambarkan pada Tabel 2 di bawah ini:

Tabel 2. Penerimaan Usaha Peternakan Broiler Pola Mandiri Kecamatan Karangploso

\begin{tabular}{ccc}
\hline Tahun & Peternak & Total Penerimaan \\
\hline & Pak Suyetno & 258.790 .050 \\
& Pak Supriadi & 310.374 .666 \\
& Pak Suyono & 310.075 .200 \\
& Pak Bu Ani & 379.080 .000 \\
& Pak Adi & 421.633 .500 \\
\hline Total & & 1.679 .953 .416 \\
\hline & Pak Suyetno & 270.644 .800 \\
& Pak Supriadi & 319.348 .260 \\
& Pak Suyono & 342.672 .850 \\
& Pak Bu Ani & 417.785 .760 \\
& Pak Adi & 437.848 .320 \\
\hline \multirow{2}{*}{ Total } & & 1.788 .299 .990 \\
\hline & Pak Suyetno & 288.000 .960 \\
& Pak Supriadi & 342.405 .441 \\
& Pak Suyono & 359.371 .738 \\
& Pak Bu Ani & 435.360 .870 \\
& Pak Adi & 463.700 .248 \\
\hline
\end{tabular}

Sumber: Data Primer Diolah, 2019

Tabel 2 menjelaskan bahwa rataan penerimaan pada tahun 2016 total penerimaan peternak broiler pola mandiri sebesar Rp.1.679.953.416, tahun 2017 sebesar Rp.1.788.299.990, tahun 2018 sebesar Rp.1.888.839.257. Hasil pengolahan data primer pada tabel 2 menunjukkan bahwa jika skala skala usaha kecil maka hasil produksinya sedikit serta pada tahun 2016 total penerimaan lebih rendah, hal ini dikarenakan tingkat mortalitas rata-rata mencapai $2,5 \%$ sehingga penerimaan peternak kecil. Penerimaan usaha ternak merupakan hasil yang diterima dari upaya penjualan pokok usaha ternak yang dijalankan, sedangkan modal yang digunakan untuk usaha tidak termasuk ada di dalamnya. Harga jual yang ditetapkan di pasar dikalikan dengan jumlah produksi usaha merupakan penerimaan kotor yang 
diperoleh melalui usaha peternakan. (Siregar, 2009). Siregar (2003) menyatakan bahwa besarnya penjualan ayam akan bergantung pada pertambahan bobot badan dan harga perkilogram ayam. Harga ditentukan berdasarkan bobot hidup ayam. Harga tersebut terus mengalami fluktuasi seiring permintaan dan penawaran pasar. Besarnya penerimaan peternak dapat dianalisa dengan cara harga produk yang telah ditetapkan dikalikan dengan besarnya jumlah produksi usaha, dan peternak mandiri bebas memasarkan produknya.

\section{Pendapatan}

Selisih besaran total penerimaan usahatani dan total pengeluaran yang harus dikeluarkan untuk biaya produksi usaha merupakan metode untuk mengetahui besaran total pendapatan usaha. Total usaha tani yang diperoleh merupakan tolok ukur keberhasilan usahatani dengan besaran uang tunai. Terdapat pula kelebihan uang tunai usahatani yang merupakan uang tunai yang dihasilkan untuk keperluan rumahtangga. Pendapatan tunai rumah tangga merupakan kelebihan uang tunai usahatani ditambah dengan penerimaan tunai rumahtangga, dimana digunakan oleh petani untuk pembayaran-pembayaran yang tidak ada kaitanya dengan usahatani. Berikut ini merupakan hasil analisa perhitungan pendapatan usaha peternakan broiler pola mandiri di Kecamatan Karangploso:

Tabel 3. Pendapatan Usaha Peternakan Broiler Pola Mandiri Kecamatan Karangploso

\begin{tabular}{|c|c|c|c|c|}
\hline Peternak & Keterangan & 2016 & 2017 & 2018 \\
\hline & & $\frac{\mathrm{Rp} / \text { tahun }}{14917051}$ & $\begin{array}{l}\text { Rp/tahun } \\
17558801\end{array}$ & Rp/tahun \\
\hline \multirow{3}{*}{ Pak Suyetno } & Keuntungan sebelum pajak & 14.917 .051 & 17.558 .801 & 20.634 .294 \\
\hline & Pajak pendapatan $1 \%$ & 149.170 & 175.588 & 206.342 \\
\hline & Keuntungan bersih (EAT) & 14.767 .881 & 17.383 .213 & 20.427 .952 \\
\hline \multirow[t]{3}{*}{ Pak Supriadi } & Keuntungan sebelum pajak & 16.374 .666 & 19.054 .927 & 22.877 .108 \\
\hline & Pajak pendapatan $2 \%$ & 327.493 & 381.098 & 457.542 \\
\hline & Keuntungan bersih (EAT) & 16.047 .173 & 18.673 .829 & 22.419 .566 \\
\hline \multirow[t]{3}{*}{ Pak Suyono } & Keuntungan sebelum pajak & 19.550 .200 & 23.678 .850 & 28.396 .238 \\
\hline & Pajak pendapatan $2 \%$ & 391.004 & 473.577 & 567.924 \\
\hline & Keuntungan bersih (EAT) & 19.159 .196 & 23.205 .273 & 27.828 .314 \\
\hline \multirow[t]{3}{*}{ Bu Ani } & Keuntungan sebelum pajak & 27.569 .668 & 33.607 .428 & 36.537 .538 \\
\hline & Pajak pendapatan $1 \%$ & 275.696 & 336.074 & 365.375 \\
\hline & Keuntungan bersih (EAT) & 27.293 .972 & 33.271 .354 & 36.172 .163 \\
\hline \multirow[t]{5}{*}{ Pak Adi } & Keuntungan sebelum pajak & 31.084 .000 & 35.833 .320 & 42.498 .340 \\
\hline & Pajak pendapatan $1 \%$ & 310.840 & 358.333 & 424.983 \\
\hline & Keuntungan bersih (EAT) & 30.773 .160 & 35.474 .987 & 42.073 .357 \\
\hline & Total keuntungan kotor & 109.468 .585 & 129.733 .326 & 150.943 .518 \\
\hline & Total keuntungan bersih & 108.041 .382 & 128.008 .656 & 148.921 .352 \\
\hline
\end{tabular}

Sumber: Data Primer Diolah, 2019

Berdasarkan hasil perhitungan data primer pada tabel 3 menunjukkan total keuntungan kotor yang diterima peternak mandiri pada tahun 2016 sebesar Rp.109.468.585, tahun 2017 meningkat sebesar Rp.129.733.326 dan pada tahun 2018 meningkat sebesar Rp.150.943.518. Keuntungan bersih (EAT) yang diterima peternak mandiri pada tahun 2016 mencapai Rp.108.041.382, tahun 2017 mencapai Rp.128.008.656 dan pada tahun 2018 sebesar Rp.148.921.352. Selisih antara pendapatan kotor dan total biaya yang harus dikeluarkan dalam proses 
usahatani merupakan metode yang digunakan untuk dapat mengetahui pendapatan bersih dan menghitung besaran nilai yang diperoleh keluarga petani sebagai upah tenaga kerjanya sendiri. Faktor yang mempengaruhi besaran nilai yang diperoleh adalah modal, baik modal sendiri atau pinjaman. Selain itu terdapat factor bagaimana cara mengatur penggunaan faktor-faktor produksi usahatani Perbandingan penampilan dari beberapa usahatani yang dijalankan merupakan suatu parameter dimana keuntungan suatu usaha layak untuk dikembangkan (Soekartawi, 2011). Hal ini sesuai dengan pendapat Suryanto (2010) yang menjelaskan hasil dari perkalian bagian-bagian produksi dengan harga bagianbagian produksi merupakan cara untuk mengetahui nilai besaran dari Revenue atau total penerimaan.

\section{Revenue Cost Ratio (R/CRatio)}

Besaran manfaat dan tambahan penerimaan yang diperoleh di setiap satu rupiah yang harus dikeluarkan setiap proses produksi berjalan disebut dengan analisa $\mathrm{R} / \mathrm{C}$ ratio. Apabila nilai ratio $>1$ maka suatu usaha dikatakan efisien, sehinggan dapat dijelaskan nilai $\mathrm{R} / \mathrm{C}$ ratio meningkat maka pengembalian yang diterima peternak dalam setiap satu rupiah secara otomatis akan meningkat pula. Jika $\mathrm{R} / \mathrm{C}<1$ maka usaha ini tidak efisien artinya petani mengalami kerugian. Hasil penerimaan yang didaptkan oleh peternak akan lebih kecil daripada total biaya yang harus dikeluarkan disetiap periode produksi (Soekartawi, 2006). Tabel 4 di bawah ini menjelaskan mengenai hasil perhitungan nilai $\mathrm{RC}$ rasio:

Tabel 4. Rasio R/C Usaha Peternakan Broiler Pola Mandiri Kecamatan Karangploso

\begin{tabular}{lcccc}
\hline \multicolumn{1}{c}{ Peternak } & $\begin{array}{c}\mathrm{R} / \mathrm{C}(\%) \\
2016\end{array}$ & $\begin{array}{c}\mathrm{R} / \mathrm{C}(\%) \\
2017\end{array}$ & $\begin{array}{c}\mathrm{R} / \mathrm{C}(\%) \\
2018\end{array}$ & $\begin{array}{c}\text { Rata-rata } \\
\mathrm{R} / \mathrm{C}(\%)\end{array}$ \\
\hline Pak suyetno & 1,06 & 1,06 & 1,07 & 1,06 \\
Pak supriadi & 1,05 & 1,06 & 1,07 & 1,06 \\
Pak suyono & 1,06 & 1,07 & 1,08 & 1,07 \\
Bu ani & 1,07 & 1,08 & 1,09 & 1,08 \\
Pak adi & 1,07 & 1,08 & 1,10 & 1,08 \\
\hline
\end{tabular}

Sumber : Data Primer Diolah, 2019

Tabel 4 menunjukkan nilai $R / C$ Ratio sebesar 1,07\%. Perhitungan tersebut menjelaskan usaha ternak ayam pedaging tersebut layak untuk dikembangkan dan dijalankan karena dinilai menguntungkan. Hasil analisa perhitungan R.C ratio yang semakin besar, semakin besar pula keuntungan yang didapatkan oleh peternak yang menjalankan usahanya. Usaha peternakan broiler pola mandiri di Kecamatan Karangploso dinyatakan layak untuk dijalankan dan dikembangkan, hal ini didukung oleh hasil pengolahan data pada Tabel 4 yang memiliki nilai $R / C$ Ratio diatas 1 . Alat untuk menganlisa imbangan antara biaya yang dikeluarkan dengan penrimaan yang didapatkan dapat ditempuh melalui perhitungan $\mathrm{R} / \mathrm{C}$ rasio. Tujuan perhitungan analisa $\mathrm{R} / \mathrm{C}$ rasio adalah agar efisiensi input dan output dapat diukur penggunaanya, cara yang dapat ditempuh adalah dengan membandingkan antara total biaya produksi yang dikeluarkan dengan penerimaan yang didapatkan. Cost 
dapat dihitung melalui total biaya yang telah dikeluarkan, sedangkan revenue dapat dihitung sebagai penerimaan hasil usaha (Gunus, 2008).

\section{Break Event Point (BEP)}

Perusahaan yang dinyatakan dalam kondisi diamana tidak mendapatkan pendapatan dan keuntungan, dan tidak pula menderita kerugian merupakan pengertian dari Break Event Point (BEP). Kondisi yang demikian berarti bahwa jumlah pendapatan yang diterima sama besarnya dengan jumlah total biaya yang harus dikeluarkan. Harga produk dapat ditentukan dengan cara menghitung nilai dari besaran BEP, dengan demikian nilai jual produk yang telah ditentukan tidak sampai membuat kerugian di dalam perusahaan (Kasmir, 2011). Berikut rataan nilai Break Event Point (BEP) usaha peternakan broiler pola mandiri Kecamatan Karangploso.

Tabel 5. Break Event Point (BEP) Usaha Peternakan Broiler Pola Mandiri Kecamatan Karangploso

\begin{tabular}{lcccccc}
\hline \multirow{2}{*}{ Peternak } & \multicolumn{2}{c}{2016} & \multicolumn{2}{c}{2017} & \multicolumn{2}{c}{2018} \\
\cline { 2 - 7 } & $\begin{array}{c}\text { BEP } \\
\text { produksi } \\
(\mathrm{Kg})\end{array}$ & $\begin{array}{c}\text { BEP } \\
\text { harga } \\
(\mathrm{Rp})\end{array}$ & $\begin{array}{c}\text { BEP } \\
\text { produksi } \\
(\mathrm{Kg})\end{array}$ & $\begin{array}{c}\text { BEP } \\
\text { Harga } \\
(\mathrm{Rp})\end{array}$ & $\begin{array}{c}\text { BEP } \\
\text { produksi } \\
(\mathrm{Kg})\end{array}$ & $\begin{array}{c}\text { BEP } \\
\text { harga } \\
(\mathrm{Rp})\end{array}$ \\
\hline Pak Suyetno & 13.290 & 17.292 & 13.462 & 17.580 & 13.711 & 18.102 \\
Pak Supriadi & 15.640 & 17.904 & 15.599 & 18.091 & 16.016 & 18.617 \\
Pak Suyono & 16.601 & 16.629 & 16.832 & 17.640 & 16.912 & 18.023 \\
Bu Ani & 19.528 & 16.690 & 20.114 & 17.563 & 19.991 & 18.875 \\
Pak Adi & 21.110 & 17.135 & 21.613 & 17.278 & 21.695 & 18.225 \\
\hline Rata rata & 86.731 & 17.130 & 87.620 & 17.656 & 88.328 & 18.368 \\
\hline
\end{tabular}

Sumber : Data Primer Diolah, 2019

Hasil pengolahan data primer pada Tabel 5 menunjukkan rataan Break Event Point (BEP) usaha peternakan broiler pola mandiri di Kecamatan Karangploso secara berurutan dimulai pada tahun 2016, 2017, dan 2018. Nilai rataan Break Event Point (BEP) harga yang didapatkan pada tahun 2016 sebesar Rp.17.130, artinya peternak ini akan mengalami posisi dimana usaha yang berjalan tidak mendapatkan keuntungan dan tidak pula mendapatkan kerugian. Apabila menjual ayam dengan harga, dengan penjualan ayam pedaging sebanyak $86.731 \mathrm{~kg}$, tahun 2017 rataan harga yang didapatkan peternak mandiri senilai Rp.17.656, dan hasil penjualan ayam sejumlah $87.620 \mathrm{~kg}$. Rataan harga usaha ayam pedaging sistem mandiri pada tahun 2018 sebesar Rp.18.368 penjualan ayam sebanyak 88.328 kg. Kesimpulan yang dapat diambil yaitu usaha peternakan broiler pola mandiri dinyatakan menguntungkan, hal tersebut dikuatkan dengan adanya hasil pengolahan data yang menjelaskan bahwa nilai BEP berbanding lurus dengan jumlah kilogram ayam broiler yang diproduksi.

\section{ROI (Return on Investmen)}

Dana didalam modal yang dimiliki oleh perusahaan yang dipergunakan untuk operasional usaha untuk mendapatkan keuntungan merupakan metode analisa ROI (Return on Investmen). Pedoman yang digunakan investor dalam 
menyusun suatu keputusan untuk berinvestasi biasanya menggunakan analisis ROI. Kinerja perusahaan yang baik ditunjukkan dengan semakin tingginya nilai ROI yang dihasilkan. Meningkatnya keuntungan yang dihasilkan dapat dipergunakan untuk menutup investasi yang telah dikeluarkan. Berikut hasil analisa perhitungan nilai ROI pada usaha peternakan broiler pola mandiri Kecamatan Karangploso:

Tabel 6. ROI (Return On Investmen) Usaha Peternakan Broiler Pola Mandiri Kecamatan Karangploso

\begin{tabular}{lcccc}
\hline $\begin{array}{c}\text { Peternak } \\
\text { mandiri }\end{array}$ & $\begin{array}{c}\text { ROI\% } \\
(2016)\end{array}$ & $\begin{array}{c}\text { ROI\% } \\
(2017)\end{array}$ & $\begin{array}{c}\text { ROI\% } \\
(2018)\end{array}$ & $\begin{array}{c}\text { Rata-rata } \\
\text { ROI(\%) }\end{array}$ \\
\hline Pak Suyetno & 4,92 & 5,79 & 6,80 & 5,83 \\
Pak Supriadi & 4,33 & 5,04 & 6,05 & 5,14 \\
Pak Supriadi & 5,04 & 6,10 & 7,32 & 6.15 \\
Bu Ani & 6,06 & 7,39 & 8,03 & 7,16 \\
Pak Adi & 6,15 & 7,09 & 8,50 & 7,24 \\
\hline
\end{tabular}

Sumber: Data Primer Diolah, 2019

Hasil pengolahan data pada Tabel 6 dapat disimpulkan bahwa nilai rataan ROI yang paling tinggi diperoleh oleh Bapak Adi yakni sebesar 7,24\%, hal tersebut menunjukkan bahwa keuntungan yang diperoleh peternak adalah tinggi. Rataan ROI terendah diperoleh Bapak Supriadi dengan nilai sebesar 5,14\%, besaran tersebut menjelaskan bahwa keuntungan yang diperoleh peternak adalah rendah. Hasil analisa sesuai dengan pernyataan Margaretha (2009) yang menjelaskan bahwa rasio yang dipergunakan sebagai alat untuk mengukur kemampuan modal yang telah diinvestasikan berupa aktiva untuk dapat menghasilkan keuntungan bersih adalah ROI. Semakin tinggi nilai ROI, maka investasi modal yang telah dikeluarkan akan dengan cepat memberikan keuntungan dalam jangka waktu periode yang lebih cepat.

\section{Payback Period (PP)}

Analisa yang dipergunakan untuk menghitung jangka waktu pengembalian investasi suatu usaha dinamakan Payback period (PP). Periode waktu yang digunakan untuk mengembalikan pengeluaran modal berupa investasi pada suatu perusahaan dengan penggunaan aliran kas. Satuan hasil yang ditentukan dalam waktu tertentu pada rasio initial cash investment dengan cash inflow-nya merupakan pengertian lain dari Payback Period (PP) (Umar, 2009). Berikut hasil pengolahan data primer yang diolah disajikan pada Tabel 7 di bawah ini:

Tabel 7. Payback Period Usaha Peternakan Broiler Pola Mandiri Kecamatan Karangploso

\begin{tabular}{lcccc}
\hline \multicolumn{1}{c}{ Peternak } & $\begin{array}{c}\text { PP } \\
\text { 2016/tahun }\end{array}$ & $\begin{array}{c}\text { PP } \\
2017 / \text { tahun }\end{array}$ & $\begin{array}{c}\text { PP } \\
2018 / \text { tahun }\end{array}$ & $\begin{array}{c}\text { Rata-rata } \\
\text { PP/Tahun }\end{array}$ \\
\hline Pak Suyetno & 1,15 & 1,10 & 1,04 & 1,09 \\
Pak Supriadi & 1,19 & 1,15 & 1,08 & 1,14 \\
Pak Suyono & 1,22 & 1,10 & 1,05 & 1,12 \\
Bu Ani & 1,18 & 1,07 & 1.03 & 1,09
\end{tabular}




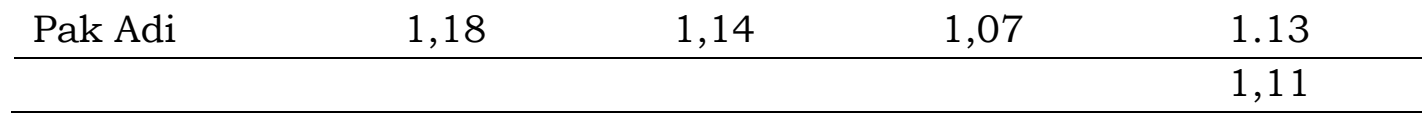

Sumber: Data Primer Diolah, 2019

Berdasarkan hasil pengolahan data yang tersaji dalam Tabel 7 diatas menunjukkan bahwa nilai rataan PP paling rendah dimiliki oleh peternak Bapak Suyetno dan Bu Ani sebesar 1,09 tahun, hal tersebut menjelaskan bahwa investasi akan dapat dikembalikan dalam jangka waktu setelah 1 tahun 1 bulan dan 2 hari. Rataan PP paling tinggi diperoleh oleh Bapak Supriyadi dengan rataan sebesar 1,14, hal tersebut menjelaskan bahwa investasi akan dapat dikembalikan dalam jangka waktu setelah 1 tahun 2 bulan. Nilai Payback Period pada usaha peternakan broiler pola mandiri di Kecamatan Karangploso menunjukan bahwa usaha tersebut layak untuk di kembangkan karena mampu menghasilkan keuntungan. Sesuai dengan pendapat (Rachadian dkk, 2013) yang menyatakan bahwa kriteria pada pengukuran ini adalah jika umur ekonomis suatu usaha lebih pendek maka usaha dapat dinyatakan layak untuk dijalankan dan dikembangkan. Sedangkan jika suatu perusahaan mempunyai nilai ekonomis yang panjang dari waktu pengembalian investasi yang maksimum maka perusahaan dikatakan kurang layak untuk dikembangkan.

\section{KESIMPULAN DAN SARAN}

\section{Simpulan}

Hasil penelitian yang telah dilaksanakan dan dianalisa pada usaha peternakan ayam broiler berpola mandiri di Kecamatan Karangploso Kabupaten Malang dapat ditarik kesimpulan. Kesimpulan yang dapat diambil yaitu rataan usaha peternakan ayam broiler berpola mandiri di Kecamatan Karangplosos Kabupaten Malang layak untuk dijalankan, hal tersebut dapat dilihat dari nilai angka BEP, R/C Ratio, dan ROI meningkat dari tahun 2016, 2017, sampai dengan tahun 2018. Nilai Payback Period menurun dari tahun 2016, 2017, sampai dengan tahun 2018, sehingga usaha peternakan broiler pola mandiri dapat dinyatakan layak, dapat dikembangkan, dan memperoleh keuntungan.

\section{Saran}

Besarnya skala usaha dan manajemen kesehatan merupakan hal yang perlu diperhatikan dalam mengembangkan suatu usaha peternakan ayam broiler pola mandiri di Kecamatan Karangploso Kabupaten Malang, karena berkaitan dengan angka mortalitas atau tingkat kematian yang secara langsung mempengaruhi tingkat keuntungan.

\section{DAFTAR PUSTAKA}

Dinas Peternakan Provinsi Jawa Timur, 2018. Jumlah Produksi dan Populasi Ayam Pedaging.BPS Provinsi Jawa Timur. Surabaya.

Gumus, G. 2008. Economic analysis of oriental tobacco in Turkey. Bulgarian journal of agricultural science, 14 (No 5)2008, 470-475 agricultural academy.

Kasmir. 2008. Analisis Laporan Keuangan. Rajawali. Jakarta. 
Kasmir, 2011, “Analisis Laporan Keuangan”, Raja Grafindo Persada: Jakarta.

Margaretha, F. 2009. Manajemen Keuangan Bagi Industri dan Jasa. Grasindo ; Jakarta.

Mufid Dahlan dan Wawan Indra Setyawan. 2016. Analisa Usaha Peternakan Ayam Broiler pola kemitraan di kecamatan sumberejo kabupaten bojonegoro. Fakultas Peternakan Universitas Islam Lamongan. Lamongan.

Munawir. 2009. Analisa Laporan Keuangan . Yogyakarta: Liberti.

Pappas James L. 1995. Ekonomi Manajerial. Binarupa Aksara. Jakarta

Rachadian, F, R., Agassi, E, A., Wahyudi, S. 2013. Analisis Kelayakan Investasi Penambahan Mesin Frais Baru Pada Cv. Xyz. Journal J@TIUndip, Vol. VIII, No. 1.Sanusi, B. 2000. Pengantar Evaluasi Proyek. FEUI. Jakarta.

Rana, K., Rahman, M., \& Sattar, M. 2012. Profitability of Small Scale Broiler Production in Some Selected Areas of Mymensingh. Progressive Agriculture, 23(1-2), 101-109. https://doi.org/10.3329/pa.v23i1-2.16568

Siregar. 2009. Analisa Pendapatan Peternak Sapi Potong di Kecamatan Srabat, Kabupaten Langkat. Skripsi. Sumatera Utara: Depertemen Peternakan. Fakultas Pertanian.

Soekartawi. 2006. Analisis Usahatani. Jakarta. UI Press

Soekartawi et all. 2011. Ilmu Usahatani dan Penelitian Untuk Pengembangan Petani Kecil. Jakarta. UI Press

Solihin, M. 2009. Risiko Produksi dan Harga serta Pengaruhnya terhadap Pendapatan Peternakan Ayam Ayam Pedaging di CV AB Farm Kecamatan Bojonggenteng-Sukabumi. Skripsi : Institut Pertanian Bogor.

Sugiono. 2013. Metode Penelitian Kuantitatif Kualitatif dan R\&D. Bandung: Alfabeta.

Supriyatna, S., Wahyuni, S., Rusastra. I.W.R. (2009). Analisis Kelembagaan Kemitraan Usaha Ternak Ayam Ras Pedaging. Studi Kasus di Propinsi Bali. Seminar Nasional Teknologi dan Peternakan. hal:830-840.

Suryanto, Fajar. 2009. Pengaruh Pengetahuan Perpajakan, Sanksi Pajak dan Kesadaran Wajib Pajak Terhadap Kepatuhan Wajib Pajak Dalam Membayar Pajak. Skripsi Jurusan Akuntansi Fakultas Ekonomi Universitas Muhammdiyah Yogyakarta.

Taufik, D. I. 2013. Analisis Pengaruh Sikap Peternak Terhadap Pendapatan Pada Usaha Peternak Itik di Kelurahan Pesungar Lor Kota Tegal. . Tegal: JITP 2 (3) 201-208.

Umar Husein. 2009. Study Kelayakan Bisnis, Teknik Menganalisis Kelayakan Rencana Bisnis Secara Komprehensif, PT Gramedia Pustaka Utama, Jakarta. 
Yemima, 2014. Analisis Usaha Peternakan Ayam Broiler Pada Peternakan Rakyat Di Desa Karya Bakti, Kecamatan Rungan, Kabupaten Gunung Mas, Provinsi Kalimantan Tengah. Jurnal I 1mu Hewani Tropika 3 (1) : 27-32. 